\title{
Tackling environmental issues in the digital age through oral histories and oral traditions from the iSimangaliso Wetland
}

\author{
Isabel Schellnack-Kelly and Veli Jiyane*
}

\begin{abstract}
In the light of student protests in 2015 and 2016 relating to the \#RhodesMustFall and \#FeesMustFall movements, the significance of the historical discourse has been sidelined. This concept paper discusses the role of digital technologies as platforms to capture and disseminate oral histories, audio-visual sources, historical writings and indigenous knowledge in order to tackle environmental concerns. In South Africa, there is a moral responsibility to encourage previously ignored communities and individuals to collect and share their experiences and knowledge, particularly where this knowledge may be valuable in tackling contemporary challenges. Through better utilisation of oral histories, oral traditions, audio-visual sources, historical writings and indigenous knowledge - as well as better access facilitated by means of digital technologies - the sustainability of historical discourse, the asset-worth of these sources and the viability of the archival institutions and the similar heritage entities housing these items, could be assured. Historians and archivists need to engage actively in highlighting collections, demonstrating their relevance to contemporary challenges and interacting with society at large to ensure that the histories recorded, captured and disseminated represent all communities. Better dissemination of these information sources could provide more effective solutions to deal with contemporary environmental concerns, such as climate change.
\end{abstract}

Key words: Indigenous knowledge; oral history; oral traditions; public archival institutions; heritage entities; digitisation; iSimangaliso Wetland; climate change.

\section{Opsomming}

In die lig van student protesaksie wat verband hou met die \#RhodesMustFall and \#FeesMustFall bewegings in 2015 en 2016, blyk dit asof die belangrikheid van die historiese diskoers eenkant toe gekuif is. Hierdie konsepartikel bespreek die rol van digitale tegnologie as 'n platform waarop omgewingskwessies aangespreek kan word

* Isabel Schellnack-Kelly is a senior lecturer in the Unisa Department of Information Science, her e-mail address is schelis@unisa.ac.za; and Veli Jiyane is an associate professor in the Unisa Department of Information Science, her e-mail address is jiyangv@unisa.ac.za

How to cite this article: Isabel Schellnack-Kelly and Veli Jiyane, "Tackling environmental issues in the digital age through oral histories and oral traditions from the iSimangaliso Wetland", Historia, 62, 2, 
deur mondelinge geskiedenis, oudiovisuele bronne, historiese geskrifte en inheemse kennis vas te lê en te versprei. In Suid-Afrika is daar 'n morele verantwoordelikheid om gemeenskappe en individue, wat voorheen geïgnoreer is, aan te moedig om hulle kennis en ervaring te deel. Dit geld veral waar hierdie kennis en ervaring van waardevol kan wees om kontemporêre uitdagings aan te pak. Die volhoubaarheideur van die historiese diskoers en die waardetoevoeging van digitale bronne kan verseker word deur mondelinge geskiedenis, oudiovisuele bronne, historiese geskrifte en inheemse kennis deur middel van digitale tegnologie vas te lê en te versprei. Die aktiewe betrokkenheid van historici en argivarisse by alle gemeenskappe om versamleings sigbaar te maak, sal bydra tot 'n demonstrasie van die versamelings se relevantheid. 'n Betrokkenheid by alle gemeenskappe sal ook verseker dat die geskiedenis wat vasgelê en versprei word verteenwoordigend van die gemeenskappe is. Die doeltreffende verspreiding van inligting uit hierdie bronne kan bydra tot die vind van beter oplossings vir kontemporêre omgewingskwessies soos klimaatsverandering.

Sleutelwoorde: Inheemse kennis; mondelinge geskiedenis; mondelinge tradisie; publieke argiefinstansies; argiefversamelings; erfenis instansies; digitale tegnologie; iSimangaliso vleiland, klimaatsverandering.

\section{Introduction}

In the light of recent events - ranging from the \#RhodesMustFall movement and the destruction of paintings at the University of Cape Town (UCT) to malicious comments on social media and threats of possible damage to historical records housed at the University of the Witwatersrand (Wits) during recent student protests ${ }^{1}$ - it is evident that in the last 23 years, little effort has been generated to foster an understanding of the historical discipline or to elevate its significance. Creating better awareness and respect for the country's cultural diversity has been lost along the way and there is an urgent need for collaborative partnerships to address this.

It is the contention of this article that under the colonial and apartheid governments the role of the public archives was regarded primarily as providing additional storage for government records rather than from the perspective of their potential contribution to nation building. However, due to the existence of aids to assist the search for information, archival information can now be traced more easily. Wat this meant was that archival repositories have benefited symbiotically from the use of these tools for purposes other than those for which they were originally intended.

It has been contended by Schellnack-Kelly (2013) and the Archival Platform (2015) that the role of the public archives - that is, fulfilling a storage function for public bodies and for heritage entities - is increasingly being side lined, principally by the current dispensation. This is particularly evident from budget allocations awarded

1. Facebook News24., "Historical Records Like the Rivonia Trial Documents could be Destroyed - Nzimande", 29 February 2016. 
to national and provincial archives. ${ }^{2}$ The most probable reasons for this are the economic climate and the "proverbial financial shoestring", 3 allocated to such cultural entities. Reinforcement of the truncated status of the country's heritage entities may also be attributed to their failure to undertake endeavours that capture and disseminate narratives representative of all communities, in other words to South African society across the board. Although there have been initiatives to capture sociopolitical narratives on the armed struggle 4 (and with cognisance of the projects undertaken by South African National Parks to capture indigenous knowledge and oral histories), ${ }^{5}$ little effort has been made to disseminate the information available in the public archival repositories effectively in a medium appropriate for use by the so-called millennials.

The opportunity to utilise information technology to provide better access to and active engagement with a younger audience, has been woefully neglected by South African heritage institutions in general and the country's public archives services in particular. This article contends that much wider access to the archives under South Africa's democratic dispensation is vitally important and is relevant for two reasons. The first is that public entities must ensure that the voices of communities marginalised by the previous dispensations are captured and made available for dissemination to all sectors of South African society. Secondly, such public entities should not preserve information purely because of their aesthetic value or from a heritage perspective. The archival repositories must ensure effective access to and dissemination of the information and knowledge from a wider spectrum of information sources. This is crucial to meeting contemporary challenges effectively - challenges such as sustainable development, eradication of poverty and tackling climate change. The South African National Archives and Records Service is required, in accordance with the country's legislation regarding public archives, to document the history of communities and narratives that were neglected under the previous dispensation. ${ }^{6}$ Therefore, undertaking oral history projects with communities in remote areas, as well as obtaining narratives on past events from such individuals and communities, is being addressed with initiatives such as the current oral history projects in association with the South African National Parks Board. ${ }^{7}$

2. I. Schellnack-Kelly, "The Role of Records Management in Governance-based Evidence, Service Delivery and Development in South African Communities", PhD thesis, Unisa, 2013; and Archival Platform, State of the Archives: An Analysis of South Africa's National Archival systems, 2014 (Archival Platform, Cape Town, 2015).

3. R. Cox, Archives and Archivists in the Information Age (Neal-Schuman, New York, 2005), p 37.

4. S. Field, "Turning up the Volume: Dialogues about Memory Create Oral Histories", South African Historical Journal, 60, 2 (2008), pp 177-178.

5. Discussion with B. Kotze, National Film, Video and Sound Archives, Pretoria, 5 December 2015.

6. National Archives and Records Service of South Africa, Records Management Policy, (National Archives and Records Service of South Africa, Pretoria, 2007), p 56.

7. Discussion with B. Kotze, National Film, Video and Sound Archives, Pretoria, 5 December 2015. 


\section{Literature review}

The literature consulted for this article has been divided into three themes and discussed accordingly. These are: the value of oral history and oral traditions; the significance of indigenous knowledge; and the utilisation of digitisation in relation to access and dissemination of primary information sources.

\section{The value of oral history and oral traditions}

Under this theme, it is important to distinguish between the concepts of oral history and oral traditions. This is because both have relevance for an exploration of indigenous knowledge and information which archival institutions should be incorporating into their collections. Focusing firstly on oral history, we have the writings of scholars such as Thompson, ${ }^{8}$ Roos, ${ }^{9}$ Field, ${ }^{10}$ Moss and Mazikana, ${ }^{11}$ and Quintana. ${ }^{12}$

Oral history, as proposed by Thompson, can be used to transform both the content and purpose of historical discourse. ${ }^{13}$ The gathering of oral evidence is a valuable restorative undertaking to include communities and individuals which were marginalised (except for labour purposes) under previous dispensations. It also broadens the scope of historical discourse and makes it possible for heritage entities to infuse life into their collections, allowing greater community participation and representation in these collections. ${ }^{14}$ Oral history is a valuable undertaking in the process of collecting indigenous knowledge and using it innovatively to formulate sustainable, workable solutions to address contemporary challenges. In this light, it is contended that oral history and the collection, preservation and accessibility of oral evidence by means of digitisation can be used to interpret forgotten narratives, generate interest and widen indigenous knowledge.

Oral tradition, an important element in the concept of indigenous knowledge, is often associated with communities whose history and narratives have been largely neglected. ${ }^{15}$ It is in this context that the observance of oral traditions is relevant, for example, to the communities dependent on the iSimangaliso Wetland for their

8. P. Thompson, The Voice of the Past: Oral History, 3rd Edition (Oxford University Press, Oxford 2000).

9. H. Roos, "Eoan, Our Story: Treading New Methodological Paths in Music Historiography”, Historia, 60, 2 (2015), pp 185-200.

10. Field, "Turning up the Volume", pp 175-194.

11. W.M. Moss and P.C. Mazikana, Archives, Oral History and Oral Tradition: A RAMP Study (UN Educational, Scientific and Cultural Organization, Paris, 1986).

12. A.G. Quintana, "The Archivist and Oral Sources", in National Archives of Canada, Documents that Move and Speak: Audio-visual Archives in the New Information Age (K.G. Saur, London and New York, 1992), pp 84-89.

13. Thompson, The Voice of the Past, pp 3, 6, 13, 26.

14. Thompson, The Voice of the Past, $\mathrm{p} 2$.

15. Moss and Mazikana, Archives, Oral History and Oral Tradition, p 11. 
livelihoods - and particularly to the women of those communities. The oral traditions prevalent in this wetland were largely side-lined by the colonial and apartheid dispensations. According to Vansina there are five broad categories of oral tradition. These are formulas (described as rituals, slogans and titles); lists of place-names and personal names; official and private poetry (including historical, religious and personal poetry, chants and songs); stories (historical, didactic, artistic or personal); and legal and other commentaries. ${ }^{16}$ Because all these examples of oral traditions have been largely neglected in South Africa, particularly in the rural areas, it is the responsibility of heritage institutions such as the national and provincial archives to collect as much information as possible on these oral histories and make it accessible to as wide an audience as possible. The current situation is that the public archives do not draw any distinction between oral history and the oral tradition. However, the South African National Archives is now actively involved, together with the South African National Parks in the collection of oral histories from communities which once lived within the boundaries of the different game parks. ${ }^{17}$

Oral traditions and oral histories relating to women in communities neighbouring the iSimangaliso Wetland were collected by Jiyane and Ngulube. ${ }^{18}$ As noted by Thompson, the value of such information rekindles the importance and central role of older community members by encouraging them to share their knowledge and these narratives with the youth. ${ }^{19}$ As part of this process, as emphasised by Vansina, it is necessary to obtain recordings from people in remote villages and from communities that do not feature in mainstream archival collections. ${ }^{20}$ As noted by the Archival Platform's State of the Archives, one of the main objectives of the national and provincial public archives is now to record the narratives of communities that, historically, have been neglected by previous governments. ${ }^{21}$ It is crucial that the oral traditions and oral histories of communities and the personal accounts of events that occurred in the past are recorded and made available to researchers. The National Archives Register of Oral Sources (NAROS) is found on the database of the South African National Archives and Records Service and relates to collections that have been captured and are accessible at the National Film, Video and Sound Archives. ${ }^{22}$

16. J. Vansina, Oral Tradition as History (James Currey and Heinemann, London, 1985), pp $14,16,17,19$.

17. Discussion with B. Kotze, National Film, Video and Sound Archives, Pretoria, 20 July 2017.

18. V. Jiyane and P. Ngulube, "Prevalence of Use of Indigenous Social Networks among Women and Girl Children in a Rural Community in KwaZulu-Natal", Indilinga, African Journal of Indigenous Knowledge Systems, 11, 2 (2012), pp 206-220.

19. Thompson, The Voice of the Past, p 10.

20. Vansina, Oral Tradition as History, p 59.

21. Archival Platform, State of the Archives, 2014, p 113.

22. National Archives and Records Service website, http://www.nationalarchives.gov.za/ (Accessed 10 June 2017). 
Field warns readers against idealising oral histories and oral evidence as the preferred route to alternative or popular truths. ${ }^{23}$ This scholar further contends that oral histories unlock prospects for new insights and the use of other evidence. ${ }^{24}$ Archival facilities should provide not only for the purposes of historical discourse, but also to address contemporary concerns, such as environmental challenges, as in the case of iSimangaliso. Field has cautioned on the assertion that the purpose of oral histories is to "fill the gaps" in the archives created under previous dispensations but does contend that oral history research may uncover hidden narratives, previously ignored, and may provide new understandings. ${ }^{25}$

As noted by Field, South African oral history projects tend to concentrate on anti-apartheid resistance campaigns. ${ }^{26}$ While he agrees that these oral history projects are commendable, especially for public-funded institutions such as the public archives, there is a need to manage different archival information sources that are inclusive and representative of other audiences. For such public institutions to be sustainable, safekeeping and responsible access to reliable information that caters for the needs of all South Africans, and all disciplines, for purposes of planning, development and tackling contemporary concerns, is critical.

This is particularly so in the context of recent violent events that have resulted in damage to statues and artistic works; this shows that little has been achieved as regards generating interest in and comprehending the significance of the historical discourse. Symbols associated with heritage, the historical discipline and entities such as public archives, museums and libraries need to be more open. They also need to encompass and include information that represents and benefits all South Africans if they are to be regarded as sustainable, valuable assets to the country. The South African Constitution (1996) indicates commitment to protecting and preserving the country's diverse cultures, languages, heritage and beliefs, and to do so without discrimination. ${ }^{27}$ Thus, the safekeeping and preservation of indigenous knowledge previously neglected by colonial and apartheid dispensations is crucial to promoting South Africa's rich, diverse heritage and cultural legacies and should be undertaken responsibly with such knowledge being made accessible as and when required.

\section{Indigenous knowledge concerning climate change and sustainability}

The importance and viability of indigenous knowledge as a tool fundamental to understanding contemporary environmental challenges such as climate change and the need for Africa to consider this knowledge rather than exclusively "Western-based

23. Field, "Turning up the Volume", p 181.

24. Field, "Turning up the Volume", p 181.

25. Field, "Turning up the Volume", pp 176-177.

26. Field, "Turning up the Volume", pp 177-181.

27. G.V. Jiyane, Information and Knowledge Society and its Impact on Poverty Alleviation and Economic Empowerment among Informal Sector Women Entrepreneurs in South Africa, PhD thesis, University of Zululand, 2012. 
scientific knowledge", 28 cannot be ignored. Solutions to environmental problems experienced throughout the African continent have thus far been based largely on Western ideas and methods. The inappropriateness of many of these solutions concerning the environment was flagged in the writings of philanthropist Laurens van der Post, who declared that colonialism had "killed contemporary Africa's respect for its own great spoken literature". ${ }^{29}$

A number of scholars, including Anders Breidlid, Chilesa, Mafela and Preece, Sillitoe, Kearney, Kunnie and Goduka, and Odora Hoppers, have emphasised the importance of local communities understanding the complex ecological challenges from their own broad knowledge base. ${ }^{30}$ An understanding of the significance of different fauna and flora in their own communities and the dependency that communities associate with the sightings of such fauna and flora (or the lack thereof) for the provision of resources, provides crucial evidence on the role of indigenous knowledge when tackling current environmental challenges such as extreme weather patterns like el Niňo and la Niňa. Africa's indigenous knowledge is able to address "metaphysical, ecological, economic and scientific fields" and "worldviews and practices" communicated by means of ceremonies, practices and associated cultural values of fauna and flora. ${ }^{31}$

An article compiled by Jangawe Msuya on the importance of protecting and preserving indigenous knowledge amongst Maasai pastoralists and the Sambaa and Zigua medicine-men of Tanzania, provides excellent examples of indigenous knowledge associated with the presence, or not, of indigenous fauna and flora, and the impact such knowledge has on the livelihoods of these communities. ${ }^{32}$ In essence, Africa's sustainable economic development and poverty eradication strategies are dependent on an understanding of the environment being in place so as to ensure that the livestock have access to palatable plants in accordance with the seasons. Taking nutritional value, toxicity and medicinal properties into account is also relevant. ${ }^{33}$

28. A. Breidlid, "Culture, Indigenous Knowledge Systems and Sustainable Development: A Critical View of Education in an African Context", International Journal of Education Development, 29 (2009), pp 140-48.

29. L. van der Post, A Story Like the Wind (Penguin Books, London, 1974), p 11.

30. Van der Post, A Story Like the Wind, p 11; B. Chilesa, L. Mafela and J. Preece (eds), Educational Research for Sustainable Development (Lightbox, Gaborone, 2003); P. Sillitoe, "Let Them Eat Cake: Indigenous Knowledge, Science and the 'Poorest of the Poor'”, Anthropology Today, 16, 6 (2000), pp 3-7; M. Kearney, Worldview (Chandler Sharp, Navato, 1984); J.E. Kunnie and N.I. Goduka (eds), Indigenous Peoples' Wisdom and Power: Affirming our Knowledge through Narratives (Ashgate, Aldershot, 2003); and CA. Odora Hoppers, Indigenous Knowledge and the Integration of Knowledge Systems (New Africa Books, Cape Town, 2002).

31. Breidlid, “Culture, Indigenous Knowledge Systems, Sustainable Development', p 141.

32. J. Msuya, "Challenges and Opportunities in the Protection and Preservation of Indigenous Knowledge in Africa", International Review of Information Ethics, 7 (2007), pp 1-8.

33. Msuya, “Challenges and Opportunities”, p 2. 
Msuya further contended that indigenous knowledge should be protected and preserved, particularly medicinal plants, game reserves and the environment. ${ }^{34}$ Added to the effective protection and preservation of such knowledge is the responsible promotion and use of indigenous knowledge to create a wider awareness, and even more importantly, the availability of this information, to enable communities to tackle ecological challenges. ${ }^{35}$ As in the case of iSimangaliso Wetland and the ecological challenges that have been encountered there, some of which can be attributed to purely Westernised solutions and interests, the extensive indigenous knowledge transmitted from one generation to the next could be of great benefit in protecting the sustainability of this UNESCO World Heritage site.

Thus, the role of heritage entities such as archival institutions should not be underestimated in protecting, preserving and ensuring the responsible accessibility of indigenous knowledge databases for current and future users. Digitisation is one method that could be utilised for all of these processes. In addition, digitisation offers the prospect of promoting broader awareness on the importance of indigenous knowledge, particularly in providing relevant, sustainable solutions to ecological challenges and sustainable development endeavours on the African continent.

As reiterated by Sithole, indigenous knowledge is an essential resource for any human development process. ${ }^{36}$ The understanding and meanings drawn from practices using resources and rituals are fundamental to decision-making processes relating to hunting, fishing, agriculture, food production, water and adaptations to environmental changes. Similar findings related to indigenous knowledge and climate change challenges in Tanzania, have been discussed in an article by Elia, Mutula and Stilwell. ${ }^{37}$ This study highlights how farmers in the Maluga and Chibelela villages, used bird species, namely the white-browed coucal (Centropus superciliosus), the cattle egret (Bubulcus ibis) and the wire-tailed swallow (Hirundo smithii) to predict climatic conditions. Similarly, the presence of insects such as millipedes, army worms, termites, butterflies and grass-green grasshoppers are used as indicators of climatic predictions. ${ }^{38}$ From works such as this, it is evident that preserving and protecting indigenous knowledge is crucial. Simultaneously, the need to conserve the environment is also highlighted. The sustainability of the fauna and flora that provide indications of environmental challenges and climatic conditions should not be destroyed in favour of commercial gain and economic exploitation. To return to the example of iSimangaliso, indigenous knowledge is vitally important. This and the

34. Msuya, "Challenges and Opportunities", p 3.

35. Msuya, "Challenges and Opportunities", pp 4-5.

36. J. Sithole, "The Challenges Faced by African Libraries and Information Centres in Documenting and Preserving Indigenous Knowledge", IFLA Journal, 33, 2 (2007), pp 117-123.

37. E.F. Elia, S. Mutula and C. Stilwell, "Indigenous Knowledge Use in Seasonal Weather Forecasting in Tanzania: The Case of Semi-arid Central Tanzania", South African Journal of Libraries and Information Science, 80, 1 (2014), pp 18-27.

38. Elia, Mutula and Stilwell, "Indigenous Knowledge Use in Seasonal Weather Forecasting", pp 21-25. 
significance of oral traditions in capturing and transferring the knowledge from one generation to the next have been two fundamental themes of research relating to women in the communities resident in the vicinity of the iSimangaliso Wetland. ${ }^{39}$

\section{The effective dissemination of information}

As contended by Ngulube, public archives can no longer afford to exist solely for the purposes of storing old records. ${ }^{40}$ For these archival repositories to be sustainable, other endeavours should be pursued to allow more audiences to have access to the collections held there. ${ }^{41}$ Digitisation of collections of different media types will ensure broader access and, if competently executed, will also appeal to millennials wishing to access archival collections. The digitisation of collections not only allows people easier access to the archival collections, but also opens up collections so that users no longer have to be constrained by geographical proximity when wanting to access the archival information. 42

The archives should cater not only to the interests of researchers and government but also meet the needs of all individuals and communities. In the 21st century, archival repositories should be conscious of their porousness to societal processes and homilies; they can no longer be simply institutions in an age where scholars question processes and where their questioning includes needing to know what records have been produced, the processes that moulded the creation of the records and the identity of the entities which have sought to collect the materials. ${ }^{43}$

The impartiality that is associated with archival collections is recognised by scholars and researchers alike. For this reason, it becomes important for South African public archives and heritage entities to collect and include narratives from communities whose voices are as yet unheard. This information must be accessible to address contemporary challenges such as climate change, drought, sustainable development and the eradication of poverty. Archives have the capacity to emerge as

39. Jiyane, Information and Knowledge Society and its Impact on Poverty Alleviation and Economic Empowerment; V. Jiyane and P. Ngulube, "Use of Indigenous Knowledge to Determine Weather Patterns: A Case Study of Women Mussel Harvesters at KwaNganase in KwaZulu-Natal". Paper presented at the First Annual Conference of the Faculty of Communication and Information Technology (NUST), Bulawayo, Zimbabwe, 23 to 24 August 2011; and Jiyane and Ngulube, "Prevalence of Indigenous Social Networks among Women and Girl Children”, pp 206-210.

40. P. Ngulube, "Managing and Preserving Indigenous Knowledge in the Knowledge Management Era: Challenges and Opportunities for Information Professionals", Information Development, 18 (2002), pp 98-99.

41. Ngulube, "Managing and Preserving Indigenous Knowledge".

42. M. Moss and B. Endicott-Popovsky, with M.J. Dupuis, (eds), Is Digital Different? How Information Creation, Capture, Preservation and Discovery are Being Transformed (Facet Publishing, London, 2015).

43. C. Hamilton, V. Harris, J. Taylor, M. Pickover, G. Reid and R. Saleh (eds) Refiguring the Archive (David Philip, Cape Town, 2002). 
not only valuable information resources but also as "sites of contested knowledge". ${ }^{4}$ New and ever-changing technologies are pushing the boundaries of the archival institutions. The effective utilisation of digital technology should also capture indigenous knowledge through oral history collections. The valuable information and knowledge should then be easily accessible for decision-makers and developers when tackling environmental challenges such as those currently being encountered in the iSimangaliso Wetland in KwaZulu-Natal.

\section{Case study of iSimangaliso Wetland}

The iSimangaliso Wetland is a UNESCO World Heritage Site and one of the first South African sites to receive this accreditation. The area and its importance are detailed in an extensive study by Nzama. ${ }^{45}$ This unique wetland has beaches which are among the few remaining protected areas to which loggerhead and leatherback turtles regularly return to lay eggs. The wetland incorporates a variety of ecosystems, ranging from the Lebombo mountain range to grasslands, forests, wetlands, mangroves, dune forests, unbroken $200 \mathrm{~km}$ stretches of white beaches, off-shore coral reefs and Africa's largest estuary. ${ }^{46}$ The case of iSimangaliso also represents a milestone for conservationists and for public pressure in curtailing the exploitative nature of multinational corporations. Concerted efforts have succeeded in thwarting attempts to strip mine the Eastern shore and dunes for titanium and other heavy minerals. ${ }^{47}$

In 1990, Frost conducted a study on Lake St Lucia, investigating the contemporary concerns relating to global warming, ozone depletion, desertification and loss of species in the area. ${ }^{48}$ This research project was an initiative under the auspices of the United Nations World Commission on Environment and Development and its focus was to launch an urgent intervention concerning development and sustainable resource management to avoid bankrupting future generations of the natural resources that were becoming issues on the global stage. ${ }^{49}$

Other research studies of a similar nature to Frost's work have been conducted on the environmental problems unleashed in the wetland and its immediate proximity. Notable examples are studies by Dominy, Koch and Bainbridge. According to these investigations, many of the problems that have arisen can be attributed to human

44. Hamilton, Harris, Taylor, Pickover, Reid and Saleh (eds), Refiguring the Archive, pp 1516.

45. A.T. Nzama, "The Nexus between Sustainable Livelihoods and Ecological Management of the World Heritage Sites: Lessons from iSimangaliso World Heritage Park, South Africa", Inkanyiso: Journal of Human and Social Science, 1, 1 (2009), pp 34-43.

46. Nzama, "The Nexus between Sustainable Livelihoods".

47. E. Koch, Reality of Rhetoric? Ecotourism and Rural Reconstruction in South Africa, (UN Research Institute for Social Dialogue, Geneva, 1994), pp 2, 48.

48. S.J. Frost, Lake St Lucia: Public Opinion, Environmental Issues and the Position of the Government, 1964-1966 and 1989-1990: A Case Study in Changing Attitudes to Conservation (University of Natal Press, Pietermaritzburg, 1990).

49. Frost, Lake St Lucia, p 3. 
interventions and the preference for Westernised solutions to environmental issues, rather than consulting local communities and applying indigenous knowledge. These scholars agree that there was a general disregard by the colonial and apartheid governments of the significance of the wetland to the local communities - people whose livelihoods and sustainability were, and indeed still are, intricately linked to iSimangaliso Wetland. 50

In 1884 iSimangaliso was occupied by the British, with the estuary being occupied to prevent German merchants from establishing a foothold in south east Africa, and to hinder Boer expansion. During this time, indiscriminate hunting practices were widespread. This was despite mediocre attempts in the 1890 s to protect large game, with legislative instruments promulgated by the Natal government. However, little consideration was directed at protecting the region's fragile ecosystems. ${ }^{51}$ Lake St Lucia was proclaimed a game reserve in 1897. The Hlabisa Game Reserve, occupying the area from False Bay up to and including the current Hluhluwe and Umfolosi game reserves and south to Cape St Lucia, was proclaimed in 1905.52

The first conscious effort to acknowledge the importance of protecting the entire ecosystem of the wetland was in 1927 when the St Lucia Bird Sanctuary was proclaimed. This proclamation included the entire lake and the eastern shores. The venture may be regarded as one of the earliest such initiatives in South Africa's conservation history. ${ }^{53}$ Despite the 1927 proclamation, during the same year, sugar cane became a key agricultural pursuit and the Umfolosi flats were opened up to serve these commercial needs. To prevent flooding, drainage and canalisation, measures were embarked upon to manage the swamps; and in the 1950s, pine forests were introduced to satisfy the interests of the pulp and paper industries. All of these agricultural and commercial activities produce large quantities of silt affecting the estuary, resulting in high salt content which had (has) an impact on the fish species, found in the wetland. Simultaneously the concentration of silt resulted in the closure of the estuary mouth. 54

In 1952, a complex engineering feat was embarked upon. This was the reengineering of a separate mouth from the Umfolosi River to channel the accumulated silt directly into the sea. From 1952 until 1962, the mouth of the wetland had to be periodically, artificially dredged due to lowered hydraulic pressure. In 1961, a proposal was made to construct the Hluhluwe Dam, specifically to serve the irrigation needs of

50. See G. Dominy, "Lake St Lucia, the Eastern Shores: Cultural Resources in Historical Perspective," Southern African Humanities, 6, 10 (1994), pp 198-202; Koch, Reality of Rhetoric, pp 18-19; W.R. Bainbridge, "Rationalization of the Commercial Afforestation Program on the Western Shores of Lake St Lucia for Nature and Wilderness Conservation, KwaZulu-Natal Province, South Africa, USDA Forest Service Proceedings, RMRS-P-27 (2003).

51. Frost, Lake St Lucia, pp 16-18.

52. Dominy, "Lake St Lucia, the Eastern Shores", p 200.

53. Dominy, "Lake St Lucia, the Eastern Shores", p 200.

54. Frost, Lake St Lucia, pp 19--20. 
the sugar farmers. The construction of this dam, and the subsequent public outcry on the threat that the dam would pose to the wetland, were instrumental in the government of the day convening the Kriel Commission of 1964-1966. This commission was tasked with investigating the perceived threats to the estuarine area.

The threats were identified as: siltation and inadequate salinity variations due to the side effects of catchment agriculture activities; the decrease in freshwater and seepage water into the estuary; the erratic sea/estuary connection with regard to sedimentation; water-absorbing afforestation; the drainage of swamps to prevent silt filtration; the diversion of the Umfolosi to reduce the amount of water leaving the estuary; the formation of sandbars and closing of the mouth; the threats from industrial and agricultural undertakings in the catchment area; and the pollution of the lake. 55

Many of the concerns raised by the Kriel Commission are still evident and are among the current challenges affecting the iSimangaliso Wetland. Similarly, many of the commission's recommendations are still current concerns, never having been comprehensively addressed by subsequent administrations. These concerns include the following: Firstly, that the salinity of the wetland needs to be controlled to ensure that there will be fresh water in the wetlands. Secondly, the construction of storage dams and the establishment of a canal system linking the Pongola Dam to the Mkuze River, which flowed into the estuary, were recommended, and this remains a priority. Thirdly, it was further recommended that the estuary's siltation be controlled by catchment farming methods, dams and swamp protection to serve as natural filters. Fourthly, the mouth of the estuary was to be kept open by dredging and an area in the estuary, referred to as the "narrows" was to be deepened and enlarged, and the separate Umfolosi mouth was to be retained. Fifthly, pollution needed (and still needs) to be controlled and regulated in the catchment area. Sixthly, the displaced communities had to be adequately provided for. Finally, biological and scientific research was encouraged. ${ }^{56}$

Despite the recommendations of the Kriel Commission, the pulp and paper industry continued to expand the pine forests; and the Hluhluwe Dam was constructed. Forest plantations of pine and eucalyptus trees are still a prominent feature of the Cape Vidal, Sodwana and Ndlozi landscapes. This is despite the negative effects on the natural environment and on indigenous forests, as well as on silt seepage into the waters of the estuary. In addition, $5600 \mathrm{~km}$ of the Dukuduku forest was leased for sisal growing, and sugar plantations have consumed and polluted the river system. ${ }^{57}$ Any efforts to allow the rivers to flow naturally have been thwarted.

From the 1970s, prospecting for metals and minerals became another threat to the sustainability of the iSimangaliso Wetland. This reached a pinnacle in the early 1990s when a mining consortium planned to strip mine the sand dunes. However, due to public pressure, petitions to save the wetland and dunes, and the dedication of local

55. Frost, Lake St Lucia, p 21.

56. Frost, Lake St Lucia, p 36.

57. Frost, Lake St Lucia, pp 44, 46. 
conservationists, the sand dunes of iSimangaliso symbolise a victory of the country's environmental movement. In the spirit of a democratic dispensation and a constitution that promotes respect for diversity of cultures, languages, heritage and beliefs, the importance of protecting iSimangaliso's "rich history, ecological and biological diversity" must be done in tandem with social justice. ${ }^{58}$ Forced removals and relocation of communities, and the dispossession of natural resources, are the legacies of the colonial and apartheid regimes. Thus, the role of communities in ensuring the sustainability of the iSimangaliso Wetland for agricultural and other economic pursuits and the importance of fauna and flora in facilitating and predicting climatic conditions cannot be underestimated. Coupled to these is their knowledge, which is equally important and is fundamental to the culture, language and heritage of the wetland's neighbouring communities.

\section{Discussion and recommendations}

The oral histories from all South African communities must be researched, documented and digitised to make them more accessible to the wider South African community. Achieving this will ensure that all sectors of society are represented in a collective archival heritage. In turn, this information should then be used to encourage the formulation of coherent solutions to contemporary challenges. The country's archival legislation lays down that these public institutions are required to document aspects of the nation's experience that were previously absent in archival repositories. ${ }^{59}$ The one field that has been neglected is the collection, preservation and disseminating of information acquired from indigenous knowledge.

Msuya describes indigenous knowledge as local or traditional knowledge that influences planning and decision-making in local areas. ${ }^{60}$ This knowledge has relevance in relation to economic development, culture preservation and political transformation. By accessing information on embedded community practices, institutions, relationships and rituals, indigenous knowledge could facilitate the reduction of poverty by managing crop production and predicting climatic conditions. ${ }^{61}$ It is critical to have an information source that is representative of all communities.

The fact that the draft iSimangaliso Wetland Integrated Plan (2017-2021) gives credibility to the rich cultural heritage associated with this world heritage site and illustrates the importance of preserving the ecosystems as well as the associated cultural heritage. 62 The "living heritage" and "age-old traditions"63 captured in oral

58. Koch, Reality of Rhetoric, $\mathrm{p} 48$.

59. Department of Arts and Culture, Records Management Policy Manual (National Archives and Records Service of South Africa, 2007), p 56.

60. Msuya, "Challenges and Opportunities", p 3.

61. Msuya, "Challenges and Opportunities", p 3.

62. “iSimangaliso Wetland Park Integrated Management Plan (2017-2021) Draft”, pp 23, 30.

63. "iSimangaliso Wetland Park Integrated Management Plan", p 23. 
narratives, cultural traditions such as songs and dance, and indigenous knowledge systems ${ }^{64}$ should not be sidelined. With this in mind, public archival services and similar heritage entities cannot be solely the domain of historical research and/or represent the needs of a niche component of society. In order for these entities and the provision of their services to be sustainable, the information sources that are collected, preserved and disseminated should be utilised fully and be representative of the entire spectrum of South African communities. ${ }^{65}$

It has further been postulated by Ngulube that the underlying principle of archives, libraries and other cultural entities is to provide access to materials relating to the cultural heritage of society. ${ }^{66}$ The operation of these heritage entities is not solely the creation of aids intended to assist in searching for information. Instead they should be engaging in undertakings that improve awareness and enhance their collections through effective public relations and marketing. Better utilisation of modern technology, such as digitisation, online access to collections and use of social media to showcase collections - all to ensure broader access and generate interest in new users - would boost public perception and interactions. ${ }^{67}$

Central to this paper is the fact that South African public archives and public heritage entities have, to date, largely failed to grasp and utilise opportunities to safeguard and enhance their services. This inadequacy - along with their remaining as public entities which fail to be regarded as fully functional services while simultaneously being perceived as institutions that exclude the majority of South Africans - may, in fact, lead to their demise. The many voices and purposes encapsulated in archival collections are exactly what constitute the sustainability rationale to appeal for appropriate funding allocations and to attract public support. The failure of the public archival entities to undertake and promote collections that provide the voices of the entire spectrum of South African society may be one of the reasons why, during tough economic times, the archival functions are increasingly sidelined and financial resources are channelled to "more urgent" spheres.

Very important for the sustainability of these institutions, and also in order to obtain better public support, archival collections must include collections of information sources across South African society. The degree of accessibility and dissemination of this information should be available so that interested persons and organisations can investigate contemporary challenges. The availability of a wide scope of information sources should, furthermore, generate collaborative partnerships and nation-building. Active engagement in the collection and dissemination of information sources pertinent to all communities in South Africa would symbiotically promote the sustainability of heritage services, such as the public archives services.

64. "iSimangaliso Wetland Park Integrated Management Plan", p 31.

65. Schellnack-Kelly, Role of Records Management, pp 9, 213.

66. Ngulube, "Managing and Preserving Indigenous Knowledge, pp 98-99.

67. Ngulube, "Managing and Preserving Indigenous Knowledge”, pp 98-99. 
It is the contention of this article that information professionals (be they archivists, librarians, museologists, or manuscript collectors) and their clients (be they academia, industry, teachers, local communities or individual researchers) should be pressurising these heritage custodians to acknowledge the value of oral histories and indigenous knowledge. Such collections, and indeed the preservation thereof and responsible dissemination, are crucial for such entities to be regarded as "bastions of national cultural heritage". 68 Digitisation is one of the tools that can be utilised to provide access to a wider audience. In addition, digitisation provides a platform to create better awareness on the importance of oral histories and the preservation and dissemination of the related indigenous knowledge to address contemporary concerns. Initiatives such as providing free Wi-Fi to remote areas offer the possibility of such archival collections being accessed by the majority of South Africans, including those living in remote areas. Access to such information, in turn, can help create better awareness and public involvement in current, contemporary matters resulting from ramifications based on decisions formulated in the past.

\section{Conclusion}

Under the colonial and apartheid governments, indigenous knowledge, oral histories and narratives from communities living in the iSimangaliso Wetland precinct were largely neglected in favour of written evidence and Western perceptions regarding the sustainability of the wetland's ecosystem. The ramifications of the 1952 decision to redirect the flow of the Umfolosi River to satisfy the needs of sugar farmers are still being felt today, with the current state of the wetland affected by the severe drought, the very low water levels and the high salinity present in the estuary. No evidence from local communities was collected or considered. The effects of these decisions, which ignored indigenous knowledge from people resident in the iSimangaliso Wetland ecosystem, may have exacerbated the current situation of the silting up of the estuary mouth, a matter also affected by climate change and the recent drought. As in Tanzania, as recounted by Msuya and Sithole, indigenous knowledge relating to the animals and waterfowl that frequent the wetland area are valuable in enabling communities to undertake sustainable development undertakings and in bringing them to the realisation that the area is being compromised by drought and environmental changes. ${ }^{69}$ The importance of oral histories and indigenous knowledge are crucial to the sustainability of the iSimangaliso Wetland and are invaluable in tackling contemporary environmental challenges.

According to the Zulu oral tradition, the presence of birds such as the cattle egret (inkenkane), coucal (umgugwane), hamerkop (uthekwane), swallow (inkonjane), ${ }^{70}$ as well as frogs and different insects, signifies the particular climatic

68. Ngulube, "Managing and Preserving Indigenous Knowledge", p 95.

69. Msuya, "Challenges and Opportunities", pp 6-7; Sithole, "Challenges Faced by African Libraries and Information Centres", pp 121-122.

70. H. Chittenden, Roberts Bird Guide. A Comprehensive Field Guide to over 950 Species in Southern Africa (Jacana, Johannesburg, 2012), pp 427-429. 
conditions in the wetland. Many Zulu traditions are based on interpretations of indigenous knowledge and not necessarily on Westernised scientific textbook scenarios. Equally important as protecting the iSimangaliso Wetland from exploitation by industrialists, agriculturalists and commercial exploiters is the protection and responsible dissemination of related indigenous knowledge. This knowledge is essential to local communities who are dependent on the wetland for their livelihoods; it should not be allowed to disappear.

Indigenous knowledge is a complex body of knowledge. Effective interventions are essential to ensure that this knowledge is safely captured, preserved and responsibly disseminated when required. Here it is possible to apply an analogy from an Nguni legend on the "tree of life" - also known as the buffalo thorn tree (isilahla) (Ziziphus mucronata) referred to as a wag-'n-bietjie in Afrikaans. This is the symbol used by the Wilderness Leadership School. ${ }^{71}$ According to the legend, the thorns guide us to look ahead to the future but we should never forget where we have come from. ${ }^{72}$ Planning and development should not be undertaken without consideration of the past. Indigenous knowledge has been ignored with harmful consequences. ${ }^{73}$

Collaboration with communities, assisted by digital access and the effective safekeeping of such information, should be of paramount importance. Scientists, developers, agriculturalists and industrialists must involve the wetland's local people. They must be party to all decision-making processes to ensure the longevity of the fragile ecosystem. Indigenous knowledge is vitally important in identifying climate change and formulating appropriate solutions to tackle contemporary environmental concerns. Effective initiatives to capture, preserve and disseminate the histories of all South Africans are fundamental to the sustainability of the archives and related heritage entities.

\section{REFERENCES}

Archival Platform, State of the Archives: An Analysis of South Africa's National Archival System, 2014 (Archival Platform, Cape Town, 2015).

Bainbridge, W.R., "Rationalization of the Commercial Afforestation Program on the Western Shores of Lake St Lucia for Nature and Wilderness Conservation, KwaZulu-Natal Province, South Africa", USDA Forest Service Proceedings RMRSP-27 (2003).

71. I. McCallum, Ecological Intelligence: Rediscovering Ourselves in Nature (Africa Geographic, Cape Town, 2005), p 24

72. McCallum, Ecological Intelligence, p 25.

73. B. Goldfarb, "Researchers around the World are Learning from Indigenous Communities", Ensia, pp 1-8 at http://ensia.com/features/researchers-around-theworld-are-learning-from-indigenous-communities-why-thats-a-good-thing/ (Accessed 1 June 2016). 
Breidlid, A., "Culture, Indigenous Knowledge Systems and Sustainable Development: A Critical View of Education in an African Context", International Journal of Education Development, 29 (2009).

Chilesa, B., Mafela, L. and Preece, J. (eds), Educational Research for Sustainable Development, (Lightbox, Gaborone, 2003).

Chittenden, H. Roberts Bird Guide. A Comprehensive Field Guide to over 950 Species in Southern Africa (Jacana, Johannesburg, 2012).

Cox, R., Archives and Archivists in the Information Age (Neal-Schuman, New York, 2005).

Department of Arts and Culture, Records Management Policy Manual (National Archives and Records Service of South Africa, Pretoria, 2007).

Dominy, G., "Lake St Lucia, the Eastern Shores: Cultural Resources in Historical Perspective", Southern African Humanities, 6, 10 (1994).

Elia, E.F., Mutula, S. and Stilwell, C., "Indigenous Knowledge Use in Seasonal Weather Forecasting in Tanzania: The Case of Semi-arid Central Tanzania", South African Journal of Libraries and Information Science, 80, 1 (2014).

Field, S., "Turning up the Volume: Dialogues about Memory Create Oral Histories", South African Historical Journal, 60, 2 (2008).

Frost, S.J., Lake St Lucia: Public Opinion, Environmental Issues and the Position of the Government, 1964-1966 and 1989-1990: A Case Study in Changing Attitudes to Conservation (University of Natal Press, Pietermaritzburg 1990).

Goldfarb, B., "Researchers around the World are Learning from Indigenous Communities", Ensia, pp 1-8 at http://ensia.com/features/researchers-aroundthe-world-are-learning-from-indigenous-communities-why-thats-a-good-thing/ (Accessed 1 June 2016).

Hamilton, C., Harris, V., Taylor, J., Pickover, M., Reid, G. and Saleh, R. (eds), Refiguring the Archive (David Philip, Cape Town 2002).

Jiyane, G.V., Information and Knowledge Society and its Impact on Poverty Alleviation and Economic Empowerment among Informal Sector Women Entrepreneurs in South Africa, PhD thesis, University of Zululand, 2012.

Jiyane, V. and Ngulube, P., "Prevalence of Use of Indigenous Social Networks among Women and Girl Children in a Rural Community in KwaZulu-Natal", Indilinga, African Journal of Indigenous Knowledge Systems, 11, 2 (2014).

Jiyane, V. and Ngulube, P., "Use of Indigenous Knowledge to Determine Weather Patterns: A Case Study of Women Mussel Harvesters at KwaNganase in KwaZuluNatal", Paper presented at the First Annual Conference of the Faculty of Communication and Information Technology (NUST), Bulawayo, Zimbabwe, 2324 August 2011.

Kearney, M., Worldview (Chandler Sharp, Navato, 1984).

Koch, E., Reality of Rhetoric? Ecotourism and Rural Reconstruction in South Africa, (UN Research Institute for Social Dialogue, Geneva, 1994).

Kunnie, J.E. and Goduka, N.I. (eds), Indigenous Peoples' Wisdom and Power: Affirming our Knowledge Through Narratives (Ashgate, Aldershot, 2003).

McCallum, I. Ecological Intelligence Rediscovering Ourselves in Nature, (Cape Town, Africa Geographic, 2005). 
Moss, M. and Endicott-Popovsky, B. with Dupuis, M.J. (eds), Is Digital Different? How Information Creation, Capture, Preservation and Discovery are Being Transformed (London, Facet Publishing, 2015).

Moss, W.M. and Mazikana, P.C., Archives, Oral History and Oral Tradition: A RAMP Study, (UN Educational, Scientific and Cultural Organization, Paris, 1986).

Msuya, J., "Challenges and Opportunities in the Protection and Preservation of Indigenous Knowledge in Africa", International Review of Information Ethics, 7 (2007), pp 1-8.

Ngulube, P., "Managing and Preserving Indigenous Knowledge in the Knowledge Management Era: Challenges and Opportunities for Information Professionals", Information Development, 18 (2002).

Nzama, A.T., "The Nexus between Sustainable Livelihoods and Ecological Management of the World Heritage Sites: Lessons from iSimangaliso World Heritage Park, South Africa", Inkanyiso: Journal of Human and Social Science, 1, 1 (2009).

Odora Hoppers, C.A. Indigenous Knowledge and the Integration of Knowledge Systems (Cape Town, Claremont, 2002).

Quintana, A.G., "The Archivist and Oral Sources", in National Archives of Canada, Documents that Move and Speak: Audio-visual Archives in the New Information Age (K.G. Saur, London and New York, 1992).

Roos, H., "Eoan, Our Story: Treading New Methodological Paths in Music Historiography", Historia, 60, 2 (2015).

Schellnack-Kelly, I., The Role of Records Management in Governance-based Evidence, Service Delivery and Development in South African Communities, $\mathrm{PhD}$ thesis, Unisa, 2013.

Sillitoe, P., "Let Them Eat Cake: Indigenous Knowledge, Science and the 'poorest of the poor'”, Anthropology Today, 16, 6 (2000).

Sithole, J., "The Challenges Faced by African Libraries and Information Centres in Documenting and Preserving Indigenous Knowledge", IFLA Journal, 33, 2 (2007). Thompson, P., The Voice of the Past: Oral History, 3rd Edition, (Oxford University Press, Oxford, 2000).

Van der Post, L., A Story Like the Wind (Penguin Books, London, 1974).

Vansina, J., Oral Tradition as History (James Currey and Heinemann, London, 1985). 